\title{
Distribution, Bioavailability and Ecological Risk of Heavy Metals in Surface Sediments from the Wujiang River Basin, Southwest of China
}

\author{
Shenwen Cai ${ }^{1,2}$ *, Shaoqi Zhou ${ }^{2,3}$, Junwei Cheng ${ }^{1}$, Qinghe Wang ${ }^{1}$, Ying Dai ${ }^{1}$ \\ ${ }^{1}$ College of Resources and Environment, Zunyi Normal University, Zunyi, China \\ ${ }^{2}$ Guizhou Academy of Sciences, Guiyang, China \\ ${ }^{3}$ State Key Laboratory of Subtropical Building Science, School of Environment and Energy, \\ South China University of Technology, Guangzhou, China
}

Received: 25 January 2021

Accepted: 27 April 2021

\begin{abstract}
Chemical speciation of $\mathrm{Cu}, \mathrm{Zn}, \mathrm{Mn}, \mathrm{Pb}, \mathrm{Cd}, \mathrm{As}$, and $\mathrm{Hg}$ in surface sediments from the Wujiang River Basin was analyzed by using modified BCR sequential extraction procedure. The results indicated that the mean total concentrations of all heavy metals except As were higher than their background values. $\mathrm{Cu}, \mathrm{Zn}, \mathrm{Pb}, \mathrm{As}$, and $\mathrm{Hg}$ mostly exist in a residual fraction. The $\mathrm{Mn}$ and $\mathrm{Cd}$ were dominated by the reducible fraction and exchangeable fraction, respectively. According to the risk assessment code (RAC) classification, $\mathrm{Cu}, \mathrm{Zn}, \mathrm{Pb}, \mathrm{As}$, and $\mathrm{Hg}$ posed a relatively low risk in this study area, while $\mathrm{Mn}$ and $\mathrm{Cd}$ posed a high risk in most sampling sites. The $I_{\text {geo }}$ classification manifested that $\mathrm{Cd}$ has the highest environmental risk and the pollution levels of heavy metals in the surface sediments were generally in the sequence of $\mathrm{Cd}>\mathrm{Zn}>\mathrm{Cu}>\mathrm{Pb}>\mathrm{Hg}>\mathrm{Mn}>\mathrm{As}$. The potential ecological risk index (PERI) was classified as considerable risk in two sampling sites and moderate risk in ten sampling sites. It should pay much attention to the ecological risk of heavy metals from the Wujiang River Basin which will influence the Yangtze River ecosystem eventually.
\end{abstract}

Keywords: heavy metal, the Wujiang River Basin, surface sediments, chemical speciation, ecological risk

\section{Introduction}

Heavy metal pollution is one of the most alarming environmental issues around the world due to the potential biotoxicity, persistence, accumulative characteristic, and widespread sources. It originates from the natural and anthropogenic sources. The

*e-mail: caishenwen@163.com former includes rock weathering, volcanic eruption, soil erosion, atmospheric deposition, etc. The latter includes discharge of domestic sewage and industrial wastewater, operation of mining and metal smelting, combustion of fossil fuels, utilization of agricultural fertilizer, and activities of increasing traffic [1-3]. The distribution characteristics of heavy metals in water and sediments can reflect not only the pollution status but also the potential influences on the health of aquatic ecosystems [4]. When heavy metals enter the river environment, most of them will be accumulated in the 
surface sediments through a series of physiological and biochemical processes [5]. In the meantime, the absorbed metals in sediments could be released with the changing of environmental conditions such as $\mathrm{pH}$, dissolved oxygen, conductivity, redox potential, nutrient levels, as well as the stirring of deposits caused by flowing water and benthic organisms. It then poses secondary pollution to the aquatic environment [6]. Therefore, the sediments can not only be served as a major sink for heavy metal inputs but also be a potential source of metal pollution in river ecosystems, which are considered to play an important role in recording the current and historical pollution [7].

The pollution status can be reflected by the assessment of the total concentrations of heavy metals in sediments. Nevertheless, the total concentration itself cannot provide sufficient information on the mobility and bioavailability of heavy metals, as different heavy metal forms in sediments have different stabilities and biological availabilities and result in varying ecological risks [8]. So, it is necessary to determine the speciation of heavy metals. In order to understand the characteristics of metal fractions in sediments, the three-step sequential extraction procedure proposed by the European Community Bureau of Reference (BCR) was commonly used. There are four kinds of metal fractions according to BCR method: (1) exchangeable fraction (F1, species with cation exchange sites and bound to carbonates), (2) reducible fraction (F2, bound to Fe-Mn oxides), (3) oxidizable fraction (F3, bound to organic matter and sulphides), and (4) residual fraction (F4, bound to mineral matrix) [9]. On the basis of BCR sequential extraction method, the Risk Assessment Code (RAC) classification can be chosen as a suitable way to assess the mobility and biological availability of heavy metals [10, 11]. In addition, the mobile fraction calculated as the sum of exchangeable, reducible, and oxidizable fractions was also important to assess the bioavailability and potential ecological risk of heavy metals in river ecosystems [6, $12]$.

A lot of $\mathrm{Hg}$ ore deposits were found in the Wujiang River Basin, which is located in the CircumPacific mercuriferous belt [13]. Because of the special geological background, numerous studies were conducted to investigate the geochemical cycling of $\mathrm{Hg}$ in river-reservoir ecosystem in this area [1416]. In addition, other mineral resources such as coal, zinc, iron, and manganese are also rich in the Wujiang River Basin. The mineral exploitation and discharge of sewage could result in metal contamination in the Wujiang River. The highest heavy metal evaluation index was found at Wulong where it is located in the downstream of Wujiang River compared to other sites from the Three Gorges Reservoir [17]. So, there is a necessity to concern the contamination of heavy metals due to highly background values and anthropogenic sources in the Wujiang River Basin. The main objectives of the present study were: (1) to determine the spatial distribution of seven selected heavy metals $(\mathrm{Cu}, \mathrm{Zn}, \mathrm{Mn}, \mathrm{Pb}, \mathrm{Cd}, \mathrm{As}$, and $\mathrm{Hg})$ resided in surface sediments from the Wujiang River Basin; (2) to explore the relationships between heavy metals in sediments and physic-chemical properties in overlying water; (3) to assess the mobility, potential bioavailability, and environment risk of these heavy metals.

\section{Experimental}

\section{Study Area}

The Wujiang River is the largest tributary on the south bank of the upper Yangtze River. It originates from the Wumeng Mountain in Western Guizhou Province and ends at Fuling in Chongqing, with a total length of $1037 \mathrm{~km}$ and a drainage area of $87920 \mathrm{~km}^{2}$

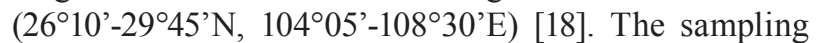
of overlying water and sediments was conducted at 26 sites from the Wujiang River Basin during January 2018. Ten of sampling sites were in the main stream of the Wujiang River, and the others were in eight tributaries, which are Liuchong River (LCR), Maotiao River (MTR), Pianyan River (PYR), Qingshui River (QSR), Xiangjiang River (XJR), Apeng River (APR), Hongdu River (HDR), and Furong River (FRR), respectively. There were two sampling sites on the middle and lower reaches of each tributary (Fig. 1).

\section{Sampling and Sample Preparation}

Surface sediment samples were collected by a Peterson grab sampler from each sampling site. Each sample was composed of six mixed sub-samples (three on the left bank and three on the right bank). The impurities such as gravel and foliage were eliminated, and then the collected sediment samples were stored in polyethylene bags. The sediment samples were air dried at room temperature, ground with agate mortars, sieved through a 200-mesh sieve, and stored in polypropylene bottles prior to analysis.

At each sampling site, the overlying water samples were collected simultaneously by a plexiglass water sampler from about $20 \mathrm{~cm}$ above the surface of sediment. They were immediately filtered through $0.45 \mu \mathrm{m}$ Millipore membrane and placed in cleaned polyethylene bottles. Ultrapure nitric acid was then added until the $\mathrm{pH}$ became less than 2 . The samples were kept in an icebox and stored at $4^{\circ} \mathrm{C}$ in a refrigerator before the experiment.

\section{Sequential Extraction}

Chemical speciation of $\mathrm{Cu}, \mathrm{Zn}, \mathrm{Mn}, \mathrm{Pb}, \mathrm{Cd}, \mathrm{As}$, and $\mathrm{Hg}$ in surface sediments was analyzed by using the BCR sequential extraction procedure according to Nemati et al. [19] with minor modifications. It could be classified into the following four forms: 


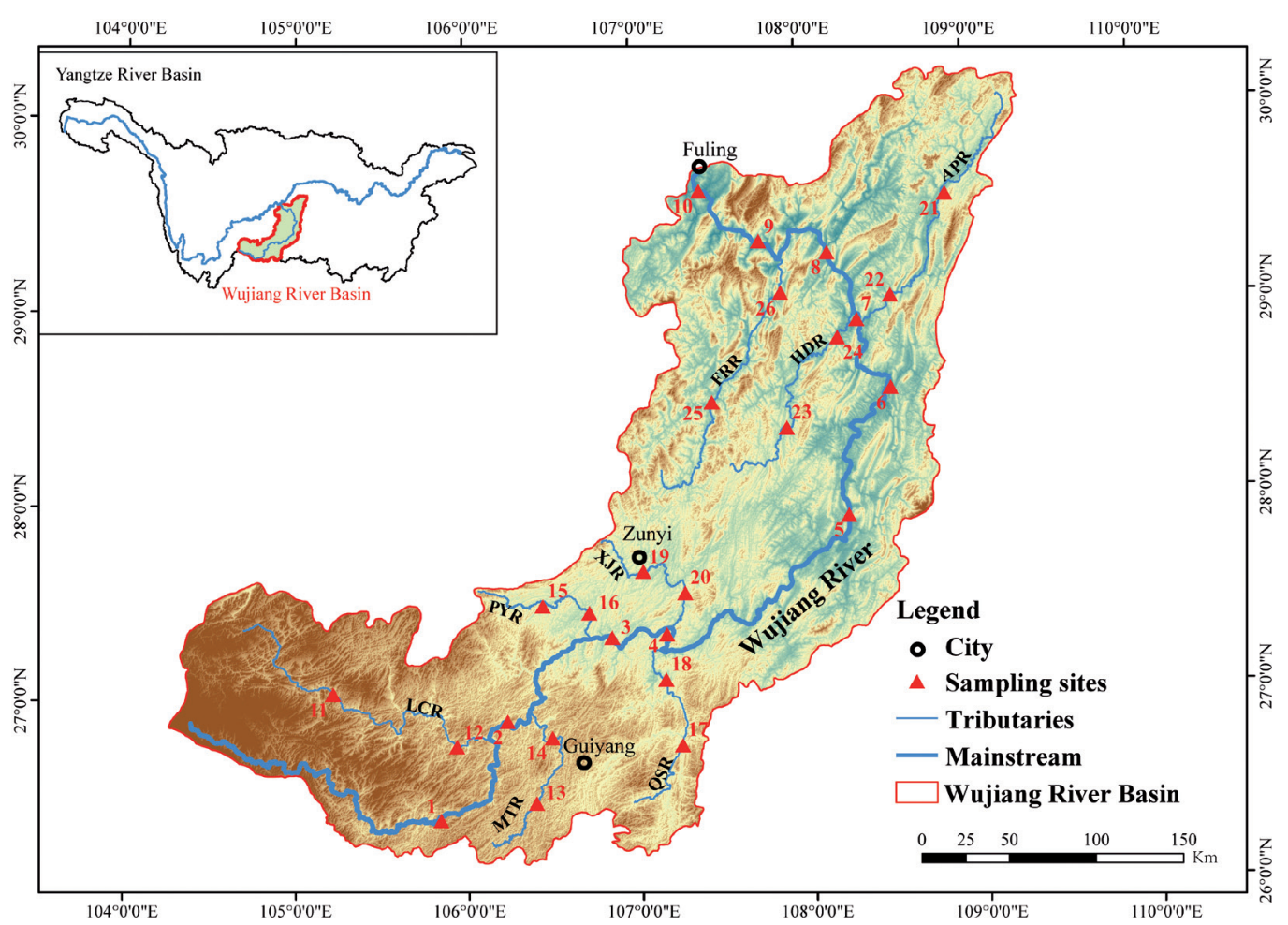

Fig. 1. Sampling sites of the surface sediments and overlying water in the Wujiang River Basin.

Exchangeable fraction (F1): $40 \mathrm{~mL}$ of $0.11 \mathrm{~mol} \mathrm{~L}^{-1}$ $\mathrm{CH}_{3} \mathrm{COOH}$ was added to $0.500 \mathrm{~g}$ sediment sample in a $100 \mathrm{~mL}$ centrifuge tube. The tube was shaken in a shaker for $16 \mathrm{~h}$ at $25^{\circ} \mathrm{C}$, then centrifuged at $5000 \mathrm{rpm}$ for $15 \mathrm{~min}$. The supernatant was decanted gently into a glass test tube and stored at $4^{\circ} \mathrm{C}$. The residue was washed with $20 \mathrm{~mL}$ deionized water twice, and the supernatant was decanted and discarded.

Reducible fraction (F2): $40 \mathrm{~mL}$ of $0.1 \mathrm{~mol} \mathrm{~L}^{-1}$ $\mathrm{NH}_{2} \mathrm{OH} \cdot \mathrm{HCl}\left(\mathrm{pH}=1.5\right.$ with $\left.\mathrm{HNO}_{3}\right)$ was added to the residue from the first step in a centrifuge tube. The supernatant and residue in this step were obtained as previously described.

Oxidizable fraction (F3): $10 \mathrm{~mL}$ of $30 \% \mathrm{H}_{2} \mathrm{O}_{2}$ was carefully added to the residue from the previous step. The digestion was proceeding at room temperature for $1 \mathrm{~h}$ with manual shaking at $10 \mathrm{~min}$ interval, and then digested at $85^{\circ} \mathrm{C}$ for $1 \mathrm{~h}$ in a water bath until the mixture was reduced to 2-3 $\mathrm{mL}$. After cooling, an additional 10 $\mathrm{mL}$ of $30 \% \mathrm{H}_{2} \mathrm{O}_{2}$ was added and repeated the above procedure. Finally, $50 \mathrm{~mL}$ of $0.5 \mathrm{~mol} \mathrm{~L}^{-1} \mathrm{NH}_{4} \mathrm{COOH}$ $\left(\mathrm{pH}=2\right.$ with $\mathrm{HNO}_{3}$ ) was added to the mixture and shaken for $16 \mathrm{~h}$ at $25^{\circ} \mathrm{C}$, then centrifuged at $5000 \mathrm{rpm}$ for $15 \mathrm{~min}$. The supernatant was decanted gently into a glass test tube and stored at $4^{\circ} \mathrm{C}$.

Residual fraction (F4): The residue from previous step was digested in a Teflon crucible with an acid mixture of concentrated $\mathrm{HCl}(4.5 \mathrm{~mL}), \mathrm{HNO}_{3}$ $(1.5 \mathrm{~mL})$, and $\mathrm{HF}(2 \mathrm{~mL})$ and heated at on a hot plate up to dryness. After cooling, the sample was dissolved in $2 \mathrm{~mL}$ of high pure $\mathrm{HCl}$, and diluted with deionized water to a volume of $25 \mathrm{~mL}$.

\section{Analytical Methods}

The common physico-chemical characteristics of overlying water (e.g., water temperature (T), $\mathrm{pH}$, dissolved oxygen (DO), saturation percentage of dissolved oxygen (DO\%), electrical conductivity (EC), and oxidation reduction potential (ORP)) were determined in situ by a portable multi-parameter water quality analyzer (YSI Professional Plus, YSI Inc., Ohio, USA). The concentrations of $\mathrm{Ca}$ and $\mathrm{Mg}$ in overlying water, and $\mathrm{Cu}, \mathrm{Zn}, \mathrm{Mn}, \mathrm{Pb}$, and $\mathrm{Cd}$ in extracted sediment solution of each steps in the BCR method were analyzed by the Shimadzu AA-6880 atomic absorption spectrophotometer. The concentrations of As and $\mathrm{Hg}$ in BCR solution were carried out by the KCHG AFS-9530 atomic fluorescence spectrophotometer. The total concentrations of heavy metals are expressed as the sum of the four fractions. Three replicates were carried out for all of the analyses, and the results were expressed as mean concentration. The relative standard deviations were less than $5 \%$. The precision and accuracy of analytical procedures were assessed by recovery measurements on sediment standard reference material GSD-7 (GBW07307). The recoveries for $\mathrm{Cu}$, $\mathrm{Zn}, \mathrm{Mn}, \mathrm{Pb}, \mathrm{Cd}, \mathrm{As}$, and $\mathrm{Hg}$ in the standard reference materials ranged from $91.4 \%$ to $108.6 \%$.

\section{Ecological Risk Assessment}

The geo-accumulation $\left(I_{\text {geo }}\right)$ is widely used as a proxy to assess the sediment pollution state [20]. It is expressed as the following equation: 


$$
I_{\text {geo }}=\log _{2} \frac{C_{\mathrm{i}}}{1.5 \times B_{\mathrm{i}}}
$$

...where $C_{\mathrm{i}}$ is measured concentration of metal $i$, and the $B_{\mathrm{i}}$ is the geochemical background concentration of metal $i$. In present study, the background concentrations of $\mathrm{Cu}$, $\mathrm{Zn}, \mathrm{Mn}, \mathrm{Pb}, \mathrm{Cd}$, As, and $\mathrm{Hg}$ were 29.43, 89.94, 1076.90, $29.39,0.31,14.89$, and $0.10 \mathrm{mg} / \mathrm{kg}$, respectively [21]. As a qualitative scale of metal pollution levels, $I_{\mathrm{geo}}$ is defined as following seven classes: class 1 (unpolluted, $I_{\text {geo }} \leqslant 0$ ); class 2 (unpolluted to moderately polluted, $0 \leqslant I_{\text {geo }} \leqslant 1$ ); class 3 (moderately polluted, $1 \leqslant I_{\text {geo }} \leqslant 2$ ); class 4 (moderately polluted to strongly polluted, $2 \leqslant I_{\text {geo }} \leqslant 3$ ); class 5 (strongly polluted, $3 \leqslant I_{\text {geo }} \leqslant 4$ ); class 6 (strongly polluted to extremely polluted, $4 \leqslant I_{\text {geo }} \leqslant 5$ ); class 7 (extremely polluted, $I_{\mathrm{geo}} \geqslant 5$ ) [22].

In order to assess the biotoxicity and comprehensive effects of heavy metals in surface sediments, the potential ecological risk index (PERI) initially introduced by Hakanson [23] was employed in present study. The PERI is defined as shown below:

$$
\text { PERI }=\sum E_{r}^{i}=\sum T_{r}^{i} \times \frac{C_{s}^{i}}{C_{n}^{i}}
$$

...where $C_{s}{ }^{i}$ and $C_{n}{ }^{i}$ are the measured concentration of metal $i$ and its background concentration, respectively. The $T_{r}^{i}$ is the biological toxicity factor of an element $i$ which is $5,1,1,5,30,10$, and 40 for $\mathrm{Cu}, \mathrm{Zn}, \mathrm{Mn}, \mathrm{Pb}$, $\mathrm{Cd}$, As, and $\mathrm{Hg}$, respectively $[23,24]$. The $E_{r}^{i}$ is the potential ecological risk factor of metal $i$. There are five classes according to $E_{r}{ }^{i}$ : low risk $\left(E_{r}{ }^{i}<40\right)$; moderate risk $\left(40 \leqslant E_{r}{ }^{i}<80\right)$; considerable risk $\left(80 \leqslant E_{r}{ }^{i}<160\right)$; high risk $\left(160 \leqslant E_{r}{ }^{i}<320\right)$; very high risk $\left(E_{r}{ }^{i} \geq 320\right)$. The PERI is the sum of $E_{r}{ }^{i}$ for all selected heavy metals. Four classes of PERI are as following: low risk $(P E R I<150)$; moderate risk $(150 \leqslant P E R I<300)$; considerable risk $(300 \leqslant P E R I<600)$; very high risk $(P E R I \geqslant 600)$.

The assessment methods of $I_{\text {geo }}$ and PERI are based on total concentrations of heavy metals in sediments, which cannot fully reflect the potential risk to water environment. Considering the mobility and biological availability of heavy metals in sediments are intensely influenced by the chemical speciation, the risk assessment code (RAC) was also used to assess the potential risk of heavy metals in this study. RAC is defined as the percentage of exchangeable fraction in the total metal concentrations ( $\mathrm{F} 1 /(\mathrm{F} 1+\mathrm{F} 2+\mathrm{F} 3+\mathrm{F} 4) \times 100 \%)$. According to RAC, the sediments were categorized into five classes: no risk ( $\mathrm{RAC}<1 \%$ ); low risk $(1 \% \leqslant \mathrm{RAC}<10 \%) ;$ moderate risk $(10 \% \leqslant \mathrm{RAC}<30 \%)$; high risk $(30 \% \leqslant \mathrm{RAC}<50 \%) ;$ very high risk $(\mathrm{RAC} \geqslant 50 \%)$.

\section{Statistical Analysis}

SPSS Statistics 13.0 and Origin 8.0 were utilized to conduct statistical analyses. The physic-chemical properties of overlying water were expressed as mean \pm standard deviation $(n=3)$. Pearson correlation coefficient was conducted to determine the relationships between the total metal concentrations in surface sediments and physic-chemical parameters in the overlying water.

\section{Results and Discussion}

\section{Physic-Chemical Properties of Overlying Water}

The physic-chemical properties of overlying water from 26 sampling sites were summarized in Table 1. The water temperature (T), percentage of dissolved oxygen (DO\%), dissolved oxygen (DO), $\mathrm{pH}$, electrical conductivity (EC), oxidation reduction potential (ORP), $\mathrm{Ca}$, and $\mathrm{Mg}$ concentrations were $8.9-16.3^{\circ} \mathrm{C}, 55.8-127.9 \%$, 5.91-12.8 mg L-1, 7.72-8.71, 138.3-495.5 $\mu \mathrm{S} \mathrm{cm} \mathrm{cm}^{-1}$, 31.4-573.6 mV, 62.6-94.1 $\mathrm{mg} \mathrm{L}^{-1}$, 9.1-15.6 mg L-1, respectively. The alkalinity and high concentrations of $\mathrm{Ca}$ and $\mathrm{Mg}$ of overlying water can be attributed to the well-developed karstification and the carbonate weathering in the Wujiang River basin [25].

\section{Distribution of Total Concentrations of Heavy Metals in Sediments}

The descriptive statistics of the total concentrations of $\mathrm{Cu}, \mathrm{Zn}, \mathrm{Mn}, \mathrm{Pb}, \mathrm{Cd}$, As, and $\mathrm{Hg}$ in surface sediments from the Wujiang River basin are listed in Table 2. The mean concentrations of the seven selected metals were decreased in the order of $\mathrm{Mn}>\mathrm{Zn}>\mathrm{Cu}>\mathrm{Pb}>\mathrm{As}>\mathrm{Cd}>\mathrm{Hg}$, which is similar to the distribution characteristics of their background values. The mean concentration of As (11.67 mg kg-1) was lower than the background value $\left(14.89 \mathrm{mg} \mathrm{kg}^{-1}\right)$, and the mean concentration of $\mathrm{Mn}$ (1110.99 mg kg-1) was comparable with its corresponding background value (1076.90 $\left.\mathrm{mg} \mathrm{kg}^{-1}\right)$. However, the mean concentrations of $\mathrm{Cu}\left(50.79 \mathrm{mg} \mathrm{kg}^{-1}\right)$, $\mathrm{Zn} \quad\left(181.99 \quad \mathrm{mg} \quad \mathrm{kg}^{-1}\right), \quad \mathrm{Pb} \quad\left(42.49 \mathrm{mg} \quad \mathrm{kg}^{-1}\right), \quad \mathrm{Cd}$ $\left(0.96 \mathrm{mg} \mathrm{kg}^{-1}\right)$, and $\mathrm{Hg}\left(0.16 \mathrm{mg} \mathrm{kg}^{-1}\right)$ were $1.73,2.02$, $1.45,3.07$, and 1.54 times higher than their background values, respectively. The total concentrations of $\mathrm{Cu}$, $\mathrm{Zn}, \mathrm{Mn}, \mathrm{Pb}, \mathrm{Cd}, \mathrm{As}$, and $\mathrm{Hg}$ in surface sediments of 26 sampling sites are shown in Fig. 2. Notably, the concentrations of $\mathrm{Zn}$ and $\mathrm{Cd}$ exceed their background values in all 26 sampling sites, and the concentration of As was higher than the background value in two sampling sites $\left(15.57 \mathrm{mg} \mathrm{kg}^{-1}\right.$ in site 4 and $17.57 \mathrm{mg} \mathrm{kg}^{-1}$ in site 13). It might be related to the high background of zinc mining area and zinc smelting activities in northwest Guizhou which are located in the upper reaches of Wujiang River. The high concentration of $\mathrm{Hg}$ in central Guizhou (site 13 and site 18) might be caused by anthropogenic source such as Guizhou organic chemical plant and high $\mathrm{Hg}$ background in Kaiyang section where Hg mine exist [26]. 
Table 1. The physic-chemical properties of overlying water from the Wujiang River Basin.

\begin{tabular}{|c|c|c|c|c|c|c|c|c|}
\hline Site & $\mathrm{T}\left({ }^{\circ} \mathrm{C}\right)$ & DO\% & $\mathrm{DO}(\mathrm{mg} / \mathrm{L})$ & $\mathrm{pH}$ & $\mathrm{EC}(\mu \mathrm{S} / \mathrm{cm})$ & ORP (mV) & $\mathrm{Ca}(\mathrm{mg} / \mathrm{L})$ & $\mathrm{Mg}(\mathrm{mg} / \mathrm{L})$ \\
\hline 1 & $10.6 \pm 0.1$ & $92.6 \pm 0.9$ & $10.30 \pm 0.10$ & $8.50 \pm 0.01$ & $280.0 \pm 1.0$ & $128.4 \pm 0.4$ & $63.1 \pm 10.9$ & $9.1 \pm 0.8$ \\
\hline 2 & $12.0 \pm 0.1$ & $80.9 \pm 1.3$ & $8.72 \pm 0.14$ & $8.11 \pm 0.02$ & $260.0 \pm 2.0$ & $491.2 \pm 0.7$ & $62.6 \pm 12.5$ & $9.7 \pm 0.8$ \\
\hline 3 & $15.3 \pm 0.0$ & $127.9 \pm 2.4$ & $12.50 \pm 0.42$ & $8.71 \pm 0.10$ & $295.6 \pm 0.7$ & $60.9 \pm 0.9$ & $70.6 \pm 11.0$ & $12.7 \pm 1.0$ \\
\hline 4 & $13.5 \pm 0.0$ & $94.4 \pm 0.5$ & $9.77 \pm 0.06$ & $8.29 \pm 0.01$ & $288.3 \pm 1.4$ & $447.9 \pm 1.7$ & $64.4 \pm 1.7$ & $11.1 \pm 1.4$ \\
\hline 5 & $13.2 \pm 0.0$ & $83.2 \pm 0.9$ & $8.72 \pm 0.10$ & $8.07 \pm 0.02$ & $284.0 \pm 0.4$ & $430.7 \pm 2.7$ & $75.4 \pm 12.0$ & $12.7 \pm 0.9$ \\
\hline 6 & $13.2 \pm 0.0$ & $90.9 \pm 0.6$ & $9.53 \pm 0.06$ & $8.21 \pm 0.02$ & $279.5 \pm 0.3$ & $32.8 \pm 0.1$ & $75.1 \pm 13.0$ & $13.5 \pm 2.2$ \\
\hline 7 & $16.0 \pm 0.1$ & $93.9 \pm 0.3$ & $8.99 \pm 0.06$ & $8.42 \pm 0.02$ & $285.4 \pm 0.3$ & $31.4 \pm 0.2$ & $73.1 \pm 10.9$ & $12.6 \pm 2.5$ \\
\hline 8 & $13.6 \pm 0.1$ & $80.2 \pm 0.7$ & $8.34 \pm 0.07$ & $8.09 \pm 0.01$ & $269.0 \pm 1.6$ & $185.3 \pm 0.7$ & $92.0 \pm 5.0$ & $13.0 \pm 2.1$ \\
\hline 9 & $13.3 \pm 0.1$ & $83.7 \pm 0.8$ & $8.74 \pm 0.08$ & $8.12 \pm 0.01$ & $257.7 \pm 1.8$ & $182.4 \pm 0.8$ & $70.0 \pm 6.2$ & $12.0 \pm 0.5$ \\
\hline 10 & $13.1 \pm 0.0$ & $83.0 \pm 0.2$ & $8.74 \pm 0.03$ & $8.03 \pm 0.03$ & $262.8 \pm 0.2$ & $181.3 \pm 0.8$ & $75.2 \pm 3.9$ & $15.0 \pm 0.5$ \\
\hline 11 & $12.3 \pm 0.0$ & $81.0 \pm 0.5$ & $8.66 \pm 0.05$ & $8.42 \pm 0.14$ & $235.2 \pm 2.6$ & $530.4 \pm 0.4$ & $78.2 \pm 2.6$ & $15.1 \pm 0.2$ \\
\hline 12 & $12.6 \pm 0.1$ & $83.4 \pm 0.5$ & $8.87 \pm 0.05$ & $8.15 \pm 0.11$ & $267.7 \pm 7.9$ & $142.1 \pm 6.0$ & $72.6 \pm 1.0$ & $11.9 \pm 0.5$ \\
\hline 13 & $10.0 \pm 0.0$ & $95.8 \pm 1.6$ & $10.80 \pm 0.06$ & $8.26 \pm 0.01$ & $350.2 \pm 0.2$ & $133.5 \pm 0.9$ & $69.4 \pm 7.8$ & $14.8 \pm 0.4$ \\
\hline 14 & $11.9 \pm 0.0$ & $93.5 \pm 1.0$ & $10.10 \pm 0.11$ & $8.21 \pm 0.02$ & $364.8 \pm 0.2$ & $129.1 \pm 0.4$ & $69.3 \pm 2.4$ & $12.3 \pm 0.3$ \\
\hline 15 & $11.2 \pm 0.0$ & $82.9 \pm 0.7$ & $9.08 \pm 0.08$ & $8.14 \pm 0.04$ & $358.3 \pm 1.1$ & $480.8 \pm 1.8$ & $70.5 \pm 3.8$ & $11.9 \pm 0.4$ \\
\hline 16 & $12.7 \pm 0.1$ & $79.2 \pm 2.1$ & $8.40 \pm 0.20$ & $8.13 \pm 0.02$ & $286.4 \pm 1.9$ & $51.2 \pm 1.4$ & $83.6 \pm 2.4$ & $14.3 \pm 0.3$ \\
\hline 17 & $11.5 \pm 0.1$ & $98.4 \pm 0.1$ & $10.70 \pm 0.01$ & $7.72 \pm 0.03$ & $362.4 \pm 4.0$ & $59.9 \pm 0.7$ & $76.4 \pm 7.0$ & $14.8 \pm 1.2$ \\
\hline 18 & $13.8 \pm 0.0$ & $108.7 \pm 0.2$ & $11.30 \pm 0.02$ & $8.43 \pm 0.02$ & $294.7 \pm 0.1$ & $44.3 \pm 0.3$ & $71.8 \pm 1.0$ & $12.5 \pm 0.2$ \\
\hline 19 & $12.6 \pm 0.0$ & $55.8 \pm 0.4$ & $5.91 \pm 0.05$ & $7.82 \pm 0.03$ & $495.5 \pm 0.1$ & $420.7 \pm 2.3$ & $73.2 \pm 2.5$ & $12.2 \pm 0.3$ \\
\hline 20 & $12.6 \pm 0.0$ & $120.7 \pm 1.4$ & $12.80 \pm 0.15$ & $8.63 \pm 0.03$ & $286.4 \pm 1.7$ & $429.7 \pm 1.1$ & $76.5 \pm 2.2$ & $13.2 \pm 0.2$ \\
\hline 21 & $8.9 \pm 0.1$ & $84.9 \pm 0.6$ & $9.79 \pm 0.04$ & $8.33 \pm 0.02$ & $138.3 \pm 0.4$ & $563.0 \pm 4.6$ & $75.1 \pm 3.0$ & $11.7 \pm 0.9$ \\
\hline 22 & $9.0 \pm 0.1$ & $85.9 \pm 0.3$ & $9.88 \pm 0.04$ & $8.12 \pm 0.03$ & $149.6 \pm 0.3$ & $573.6 \pm 2.5$ & $66.4 \pm 1.6$ & $12.5 \pm 0.2$ \\
\hline 23 & $12.5 \pm 0.1$ & $108.5 \pm 1.7$ & $11.60 \pm 0.22$ & $8.22 \pm 0.03$ & $233.4 \pm 0.2$ & $418.1 \pm 1.7$ & $70.4 \pm 5.1$ & $13.1 \pm 0.6$ \\
\hline 24 & $16.3 \pm 0.1$ & $88.3 \pm 0.2$ & $8.55 \pm 0.04$ & $8.27 \pm 0.02$ & $283.2 \pm 0.2$ & $32.4 \pm 0.3$ & $72.6 \pm 4.1$ & $13.1 \pm 0.3$ \\
\hline 25 & $11.6 \pm 0.0$ & $92.1 \pm 0.9$ & $10.0 \pm 0.10$ & $8.04 \pm 0.02$ & $305.3 \pm 0.7$ & $422.6 \pm 1.3$ & $69.8 \pm 4.9$ & $13.0 \pm 0.6$ \\
\hline 26 & $11.3 \pm 0.1$ & $94.5 \pm 0.5$ & $11.2 \pm 0.06$ & $8.17 \pm 0.03$ & $330.8 \pm 0.1$ & $343.2 \pm 1.2$ & $94.1 \pm 2.2$ & $15.6 \pm 0.1$ \\
\hline
\end{tabular}

Table 2. Descriptive statistics of the total concentrations of heavy metals $(\mathrm{mg} / \mathrm{kg})$ in surface sediments from the Wujiang River Basin and published mean concentrations of heavy metals from adjacent area.

\begin{tabular}{|c|c|c|c|c|c|c|c|c|}
\hline & $\mathrm{Cu}$ & $\mathrm{Zn}$ & $\mathrm{Mn}$ & $\mathrm{Pb}$ & $\mathrm{Cd}$ & $\mathrm{As}$ & $\mathrm{Hg}$ & References \\
\hline Mean & 50.79 & 181.99 & 1110.99 & 42.49 & 0.96 & 11.67 & 0.16 & Present study \\
\hline SD & 21.73 & 76.07 & 480.86 & 15.13 & 0.36 & 2.54 & 0.18 & \\
\hline Median & 44.19 & 147.14 & 1045.15 & 38.82 & 0.87 & 11.63 & 0.11 & \\
\hline Max & 109.66 & 381.98 & 2455.38 & 80.13 & 1.93 & 17.57 & 0.89 & \\
\hline Min & 23.94 & 120.87 & 511.32 & 22.91 & 0.41 & 6.94 & 0.05 & \\
\hline Kurtosis & 1.68 & 1.91 & 1.01 & 2.07 & 0.67 & -0.14 & 12.75 & \\
\hline Skewness & 1.49 & 1.66 & 1.05 & 1.55 & 0.90 & 0.25 & 3.51 & \\
\hline CV $(\%)$ & 42.79 & 41.80 & 43.28 & 35.61 & 37.08 & 21.76 & 111.46 & \\
\hline BV & 29.43 & 89.94 & 1076.90 & 29.39 & 0.31 & 14.89 & 0.10 & \\
\hline \% Sites>BV & $92 \%$ & $100 \%$ & $46 \%$ & $88 \%$ & $100 \%$ & $8 \%$ & $58 \%$ & \\
\hline
\end{tabular}


Table 2. Continued.

\begin{tabular}{|c|c|c|c|c|c|c|c|c|}
\hline Pengxi River & 33.92 & NA & 324.5 & 20.77 & 0.42 & NA & NA & {$[25]$} \\
\hline Jinsha River & 58.57 & 56.5 & NA & 22.23 & 0.25 & 12.45 & 0.038 & {$[26]$} \\
\hline Three Gorges Reservoir & 97.72 & 177 & NA & 114.1 & 0.33 & 10.08 & 0.05 & {$[27]$} \\
\hline Yangtze River & 82 & 174 & NA & 60 & 2.46 & 25.4 & 0.16 & {$[28]$} \\
\hline
\end{tabular}

NA: not available. BV: background value.

The coefficient of variations (CVs) of $\mathrm{Pb}$ and $\mathrm{As}$ were $35.61 \%$ and $21.76 \%$, respectively, which were classified to medium variation $(15 \%<\mathrm{CV}<36 \%)$ [27]. The CVs for $\mathrm{Cu}, \mathrm{Zn}, \mathrm{Mn}, \mathrm{Cd}$, and $\mathrm{Hg}$ were $42.79 \%$, $41.80 \%, 43.28 \%, 37.08 \%$, and $111.46 \%$, respectively, which belong to high variation $(\mathrm{CV}>36 \%)$. The higher $\mathrm{CV}$ values for these heavy metals indicated that they were unevenly distributed and probably influenced by anthropogenic sources. The skewness of the selected heavy metals followed the order of $\mathrm{Hg}>\mathrm{Zn}>\mathrm{Pb}>\mathrm{Cu}>\mathrm{Mn}$ $>\mathrm{Cd}>$ As. The skewness for $\mathrm{Hg}$ was also higher than that of the other metals, suggesting that the $\mathrm{Hg}$ in sediments may be influenced by the human activities [5]. The $\mathrm{Hg}$ concentration had a CV of $111.46 \%$, skewness of 3.51 and kurtosis of 12.75, which were the largest of all heavy metals studied.
The mean concentrations of $\mathrm{Cu}, \mathrm{Mn}, \mathrm{Pb}$, and $\mathrm{Cd}$ in sediments from present study area were higher than that found in sediments of Pengxi River, a tributary of the Yangtze River [28]. The mean concentrations of $\mathrm{Cu}$ and As in the Wujiang River Basin were comparable to those in Jinsha River, while $\mathrm{Zn}, \mathrm{Pb}, \mathrm{Cd}$, and $\mathrm{Hg}$ were much higher than those in Jinsha River, a significant source of water to the Yangtze River [29]. The mean concentrations of $\mathrm{Zn}$ and $\mathrm{Hg}$ were close to the Yangtze River, and the mean concentrations of $\mathrm{Cu}, \mathrm{Pb}, \mathrm{Cd}$, and As were lower than that found in sediments of the Yangtze River [30]. Compared with the reports about heavy metals in sediments from the Three Gorges Reservoir, the $\mathrm{Cu}$ and $\mathrm{Pb}$ were lower, but $\mathrm{Zn}, \mathrm{Cd}, \mathrm{As}$, and $\mathrm{Hg}$ were higher [31]. The Wujiang River is one of the most important input rivers for the Three Gorges
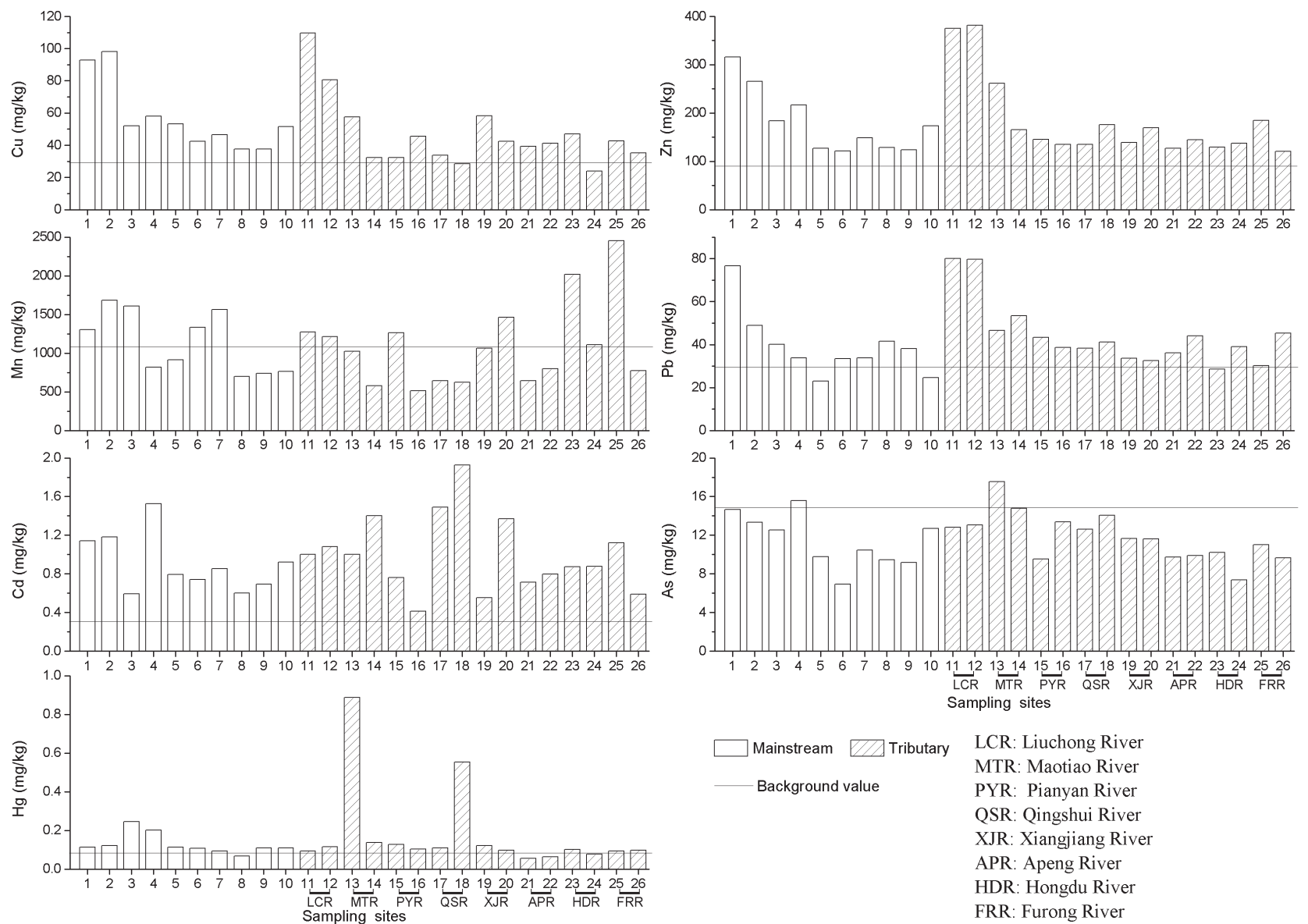

Fig. 2. The total concentrations of $\mathrm{Cu}, \mathrm{Zn}, \mathrm{Mn}, \mathrm{Pb}, \mathrm{Cd}, \mathrm{As}$, and $\mathrm{Hg}$ in surface sediments of 26 sampling sites from the Wujiang River Basin. 
Reservoir, it could be a main pollution source of heavy metals in the Three Gorges Reservoir [17].

\section{Correlation Analysis}

The results of Pearson correlation coefficient are presented in Table 3. The correlations between overlying water physic-chemical properties and the total concentrations of heavy metals in surface sediments from 26 sampling sites were complex. Significant negative correlation was shown between water temperature (T) and ORP $(p<0.01)$. Significant positive correlations were observed in the pairs $\mathrm{DO} \%$ DO (0.944, $p<0.01)$, DO $\%$-pH $(0.658, p<0.01)$, DO-pH $(0.566, p<0.01)$, and $\mathrm{Ca}-\mathrm{Mg}(0.652, p<0.01)$. There was a positive correlation of $p<0.05$ between $\mathrm{Cd}$ and DO, indicating that the distribution of $\mathrm{Cd}$ was controlled by the concentration of dissolved oxygen in this study area. In addition, the $\mathrm{Cd}$ concentration was significantly negative correlated with $\mathrm{Ca}(p<0.05)$, indicating that the $\mathrm{Ca}$ may be the main factor affecting the distribution of $\mathrm{Cd}$ in the surface sediment of the Wujiang River Basin. However, no correlations were observed between $\mathrm{Cd}$ and other parameters $(p>0.05)$. Pearson's correlation matrix also reflected close relationships among the heavy metals (Table 3). Significant positive correlations were found between several metal pairs like $\mathrm{Cu}-\mathrm{Zn}, \mathrm{Cu}-$ $\mathrm{Pb}, \mathrm{Zn}-\mathrm{Pb}, \mathrm{As}-\mathrm{Zn}$, As-Cd, and As-Hg $(p<0.01)$. Metal pair $\mathrm{As}-\mathrm{Cu}$ exhibited a significant positive correlation of $p<0.05$, which indicated common sources, mutual dependence, and migration behavior of these metals $[32,33]$. However, no significant correlation was found between $\mathrm{Mn}$ and other metals. In addition, no significant correlation exists among other metals, which reflected these metals might not be controlled by a single factor [34].

\section{Chemical Speciation of Heavy Metals in Sediments}

The chemical fraction percentages of $\mathrm{Cu}, \mathrm{Zn}, \mathrm{Mn}$, $\mathrm{Pb}, \mathrm{Cd}, \mathrm{As}$, and $\mathrm{Hg}$ in sediment from the Wujiang River Basin were illustrated in Fig. 3. $\mathrm{Cu}, \mathrm{Zn}, \mathrm{Pb}$, $\mathrm{As}$, and $\mathrm{Hg}$ appear mostly in a residual fraction with mean percentages of $79.98 \%, 73.00 \%, 67.84 \%, 93.72 \%$, and $82.23 \%$, respectively. It indicated that these heavy metals were mainly bound in the mineral lattice and could be stable under natural conditions with lower mobility and bioavailability. It is generally accepted that the sum of exchangeable fraction, reducible fraction, and oxidizable fraction is mobile fraction [6]. The relatively unstable binding forms show high bioavailability and toxicity than the residual fraction. The mean percentages of mobile fraction of heavy metals occurred in the following order: $\mathrm{Mn}(78.63 \%)>\mathrm{Cd}(67.67 \%)>\mathrm{Pb}$ $(32.16 \%)>\mathrm{Zn} \quad(27.00 \%)>\mathrm{Cu} \quad(20.02 \%)>\mathrm{Hg} \quad(17.77 \%)>\mathrm{As}$ (6.28\%). Obviously, the values of $\mathrm{Mn}$ and $\mathrm{Cd}$ were much higher than other heavy metals, indicating that $\mathrm{Mn}$ and $\mathrm{Cd}$ were more mobile and bioavailable than other studied heavy metals. Mn was dominated by the reducible fraction with a mean percentage of $39.66 \%$ and a range from $12.83 \%$ to $59.64 \%$. The exchangeable fraction of $\mathrm{Mn}$ was also found in a significant mean percentage of $37.05 \%$ and a range from $5.69 \%$ to $69.21 \%$. The relatively high proportions of exchangeable and reducible $\mathrm{Mn}$ in present study were in agreement with Zheng et al. [35]. Mn is an active element and will exist and migrate in a dissolved form in porewater [36]. Besides, a great number of Mn could be released as the water environment acidified continuously [37]. Furthermore, high levels of Mn originated from the development and utilization of local $\mathrm{Mn}$ resources might be easily attached to the surface sediments, which has also been reported in the previous study [38].

The exchangeable fraction of $\mathrm{Cd}$ was the most dominant fraction with mean percentages of $35.00 \%$ followed by the residual fraction (32.33\%), reducible fraction (30.85\%), and oxidizable fraction (1.82\%). Other studies also demonstrated that the predominance proportion of $\mathrm{Cd}$ were found in exchangeable fraction $[33,39,40]$. The ionic radius of $\mathrm{Cd}$ is $0.97 \AA$, which is similar to that of $\mathrm{Ca}(0.99 \AA)$. It should be good for the co-precipitation of $\mathrm{Cd}$ with carbonates [41]. Significant negative correlation between $\mathrm{Ca}$ in overlying water and $\mathrm{Cd}$ in sediments was shown in Table 3, indicating the $\mathrm{Ca}$ could be easily replaced by $\mathrm{Cd}$ in the form of carbonate minerals. The high mobility of $\mathrm{Cd}$ could, at least partly, explain that the total concentration of $\mathrm{Cd}$ was relatively less than other heavy metals in the present studied area. On the other hand, it also suggested that the $\mathrm{Cd}$ is regarded as one of the most contaminated metals in the Wujiang River Basin because of its higher dispersal ability. The presence of heavy metals in the exchangeable fraction is mainly due to the anthropogenic activities, such as industrial production, mining, and utilization of agricultural fertilizer [42,43]. Considering that less source of industrial production and mining because of strict environmental protection measures, the accumulating of $\mathrm{Cd}$ could be as a result of runoff containing phosphate fertilizer from the agricultural farms $[39,41]$.

\section{Assessment of Potential Ecological Risk}

The RAC value of the selected heavy metals ranged from $0.08 \%$ to $3.67 \%$ with an average of $1.04 \%$ for $\mathrm{Cu}, 0.14 \%$ to $12.34 \%$ with an average of $4.17 \%$ for $\mathrm{Zn}, 5.69 \%$ to $69.21 \%$ with an average of $37.05 \%$ for $\mathrm{Mn}, 0.62 \%$ to $4.56 \%$ with an average of $1.76 \%$ for $\mathrm{Pb}$, $10.10 \%$ to $51.47 \%$ with an average of $35.00 \%$ for $\mathrm{Cd}$, $1.40 \%$ to $3.25 \%$ with an average of $2.01 \%$ for As, $0.82 \%$ and $19.04 \%$ to with an average of $8.01 \%$ for $\mathrm{Hg}$ (Fig. 3). According to the RAC classification, $\mathrm{Cu}, \mathrm{Zn}, \mathrm{Pb}, \mathrm{As}$, and $\mathrm{Hg}$ posed a low risk in the Wujiang River Basin. However, it cannot be ignored that the moderate risk of $\mathrm{Hg}$ were shown in sampling sites of 8, 21, and 22, indicating higher potential mobility and bioavailable risk than other sites. $\mathrm{Mn}$ and $\mathrm{Cd}$ posed a high risk in 


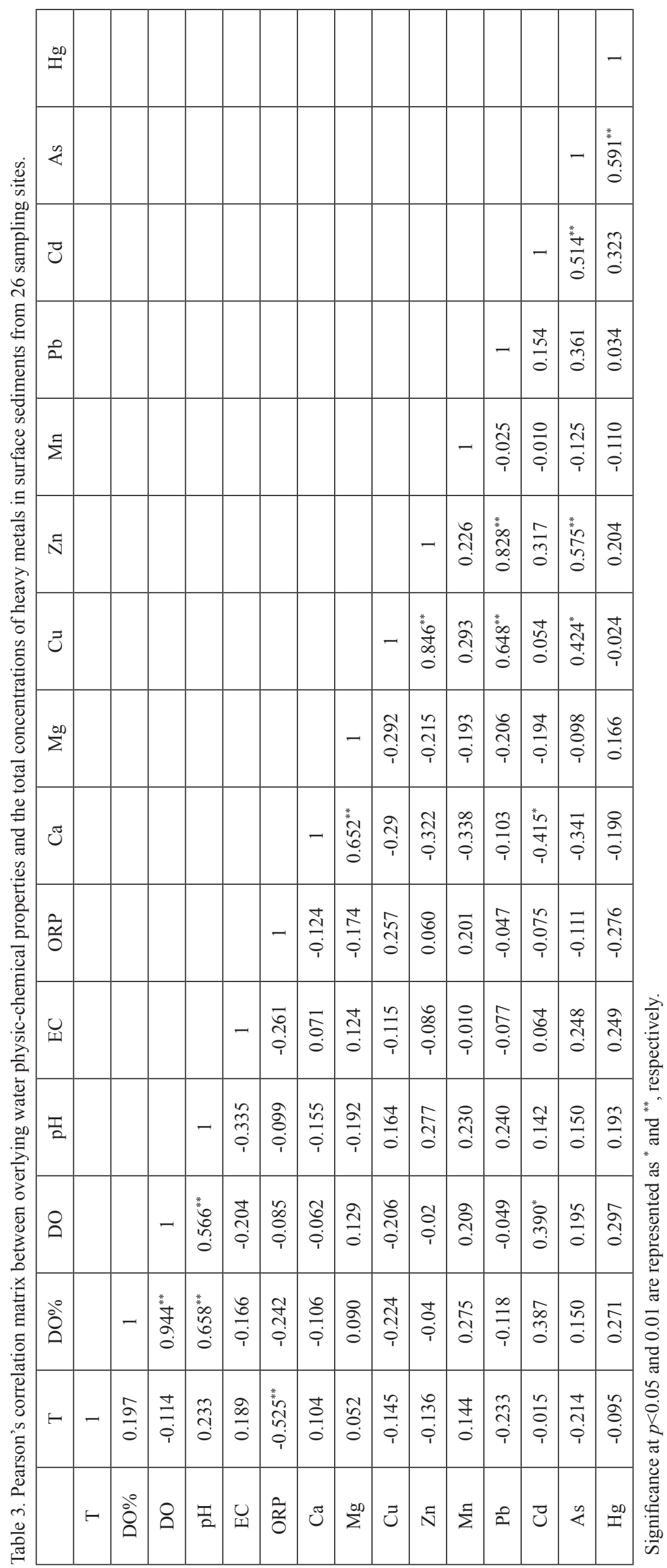


more than $53 \%$ and $73 \%$ sampling sites, respectively. In addition, Mn was associated with very high risk in sites of $8,11,15$, and 24 . Cd was associated with very high risk in sites of 23 and 24, which is located in the HDR.

The $I_{\text {geo }}$ values for the present study area are shown in Fig. 4. It can be seen that the $I_{\text {geo }}$ values of As in all sampling sites were less than 0 , indicating no pollution. Although $11.5 \%$ and $26.9 \%$ of sampling sites of Mn and $\mathrm{Pb}$ were classified as unpolluted to moderately polluted, the average values were less than 0 . It suggested that the pollution degree of $\mathrm{Mn}$ and $\mathrm{Pb}$ in the Wujiang River Basin was no pollution. The average $I_{\text {geo }}$ value of $\mathrm{Hg}$ was less than 0. However, it cannot be ignored that degrees of moderately polluted and moderately polluted to strongly polluted were shown in sites of 18 and 13, respectively. $38.5 \%$ of sampling sites for $\mathrm{Cu}, 61.5 \%$ for $\mathrm{Zn}$ were unpolluted to moderately polluted, and the average $I_{\text {geo }}$ values of $\mathrm{Cu}$ and $\mathrm{Zn}$ were 0.10 and 0.34 , respectively, indicating mild pollution. The $I_{\text {geo }}$ values of $\mathrm{Cd}$ in all sampling sites were above 0 with the exception
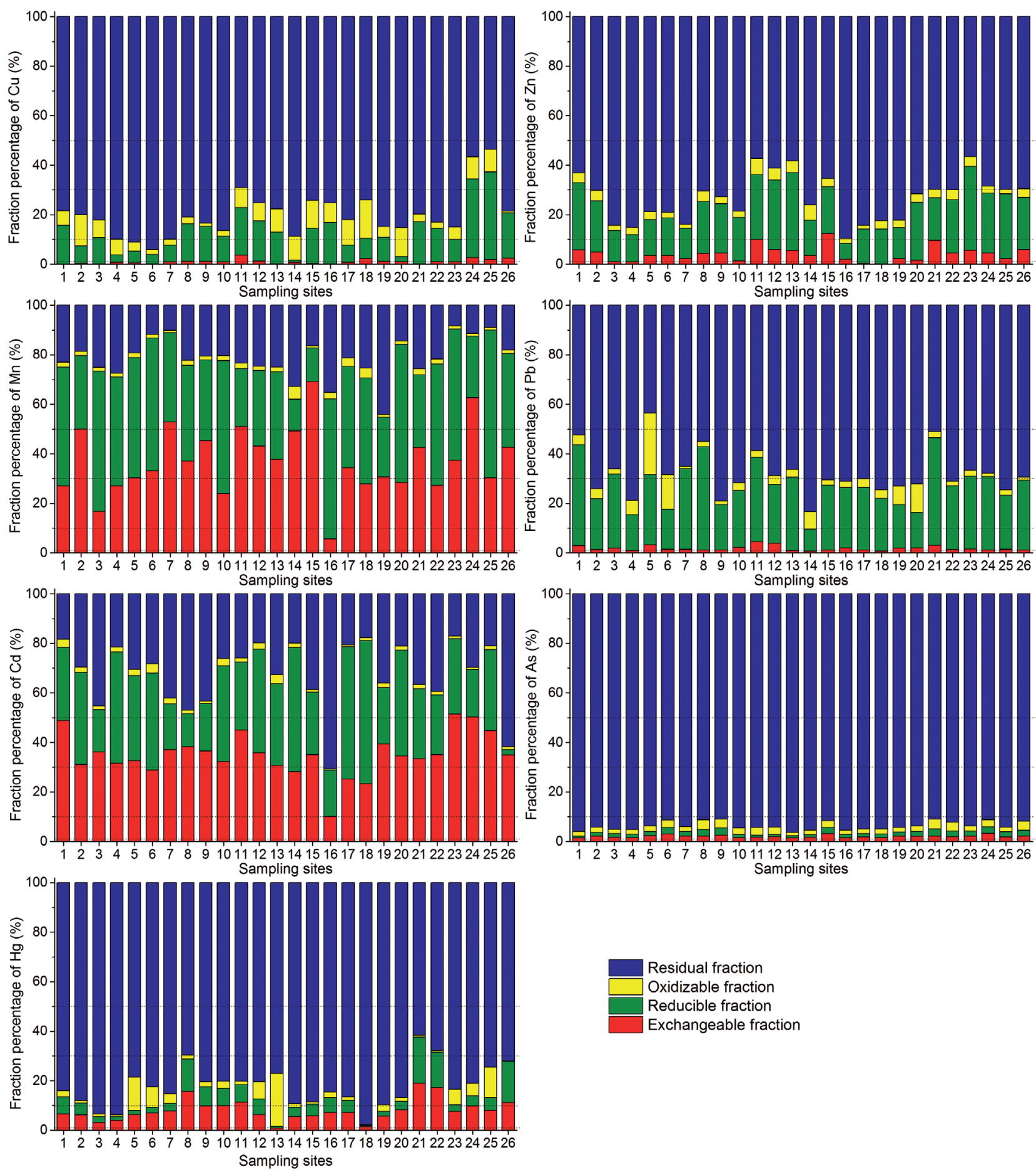

Sampling sites

Residual fraction

Oxidizable fraction

Reducible fraction

Exchangeable fraction

Fig. 3. The chemical fractions of $\mathrm{Cu}, \mathrm{Zn}, \mathrm{Mn}, \mathrm{Pb}, \mathrm{Cd}, \mathrm{As}$, and $\mathrm{Hg}$ in surface sediments of 26 sampling sites from the Wujiang River Basin. 


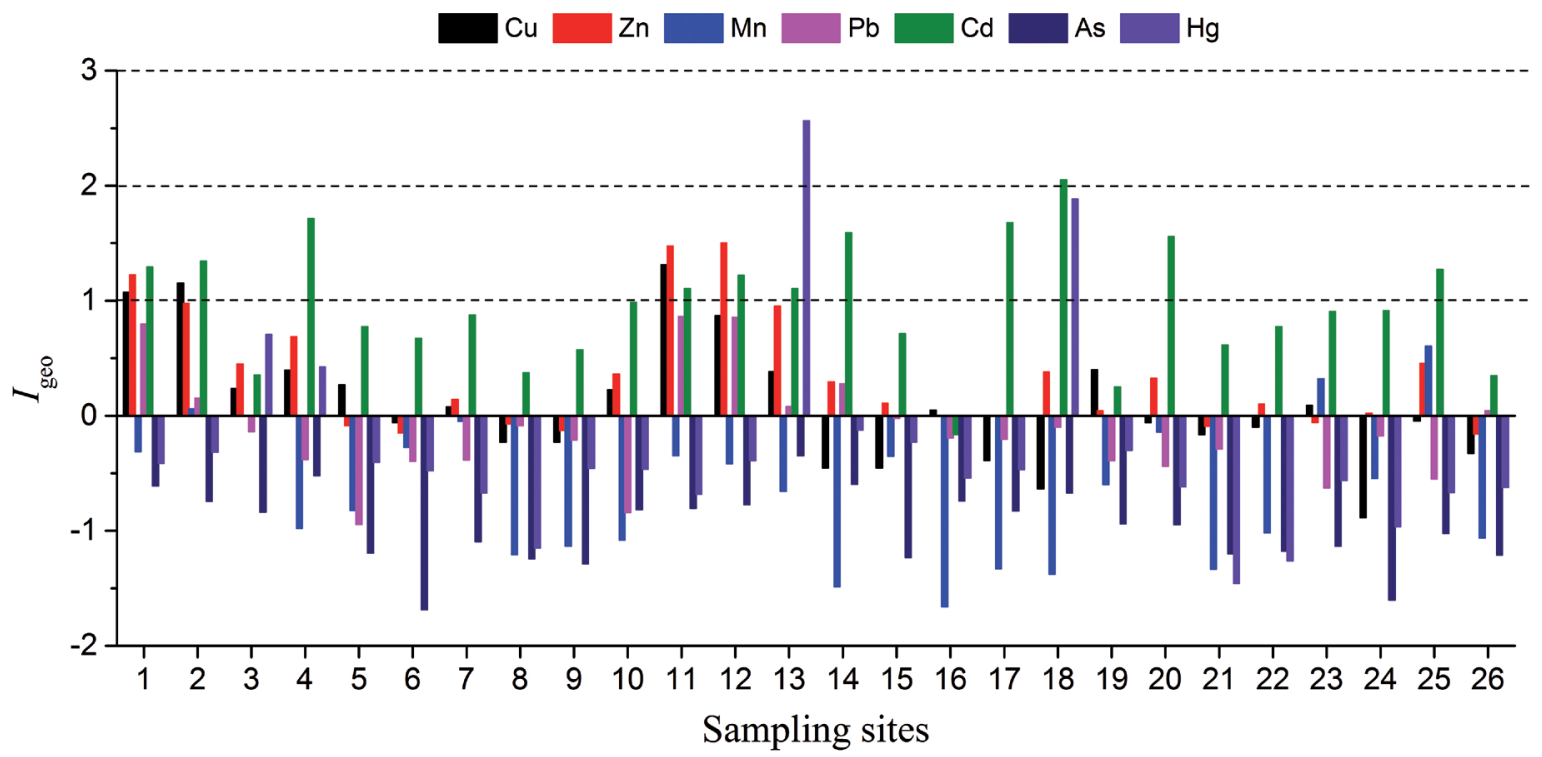

Fig. 4. The Igeo values of heavy metals in surface sediments of 26 sampling sites from the Wujiang River Basin.

of site $16.38 .5 \%$ of sampling sites were moderately polluted, and it was moderately polluted to strongly polluted in site 18. In summary, the pollution levels of heavy metals with respect to $I_{\text {geo }}$ classification in the surface sediments of the Wujiang River Basin were generally in the order of $\mathrm{Cd}>\mathrm{Zn}>\mathrm{Cu}>\mathrm{Pb}>\mathrm{Hg}>\mathrm{Mn}>\mathrm{As}$.

The $E_{r}{ }^{i}$ and PERI analysis results of selected heavy metals in the sediments of the studied area are represented in Fig. 5. The values of $E_{r}{ }_{r}$ in each sampling site for $\mathrm{Cu}, \mathrm{Zn}, \mathrm{Mn}, \mathrm{Pb}$, and As were far less than 40, indicating a low potential ecological risk. The $E_{r}{ }^{i}$ values of $\mathrm{Hg}$ ranged from 21.9 to 354.9 and with an average of
63.31. A total of $22(84.6 \%)$ sampling sites exhibited a low or moderate risk, two sampling sites presented considerable risk, one presented high risk and one presented very high risk. The $E_{r}{ }^{i}$ values of $\mathrm{Cd}$ in all sampling sites were above 40, ranged from 41.1 to 186.3 , with an average of 93.1. More than half of the sampling sites showed a considerable risk. The sampling site of 18 posing a high risk due to the high level of $\mathrm{Cd}$ in this site. Overall, the average PERI value (183.13) for all studied heavy metals in the surface sediment of the Wujiang River Basin was classified as moderate risk. Fourteen sampling sites of the PERI values were lower than 150 ,

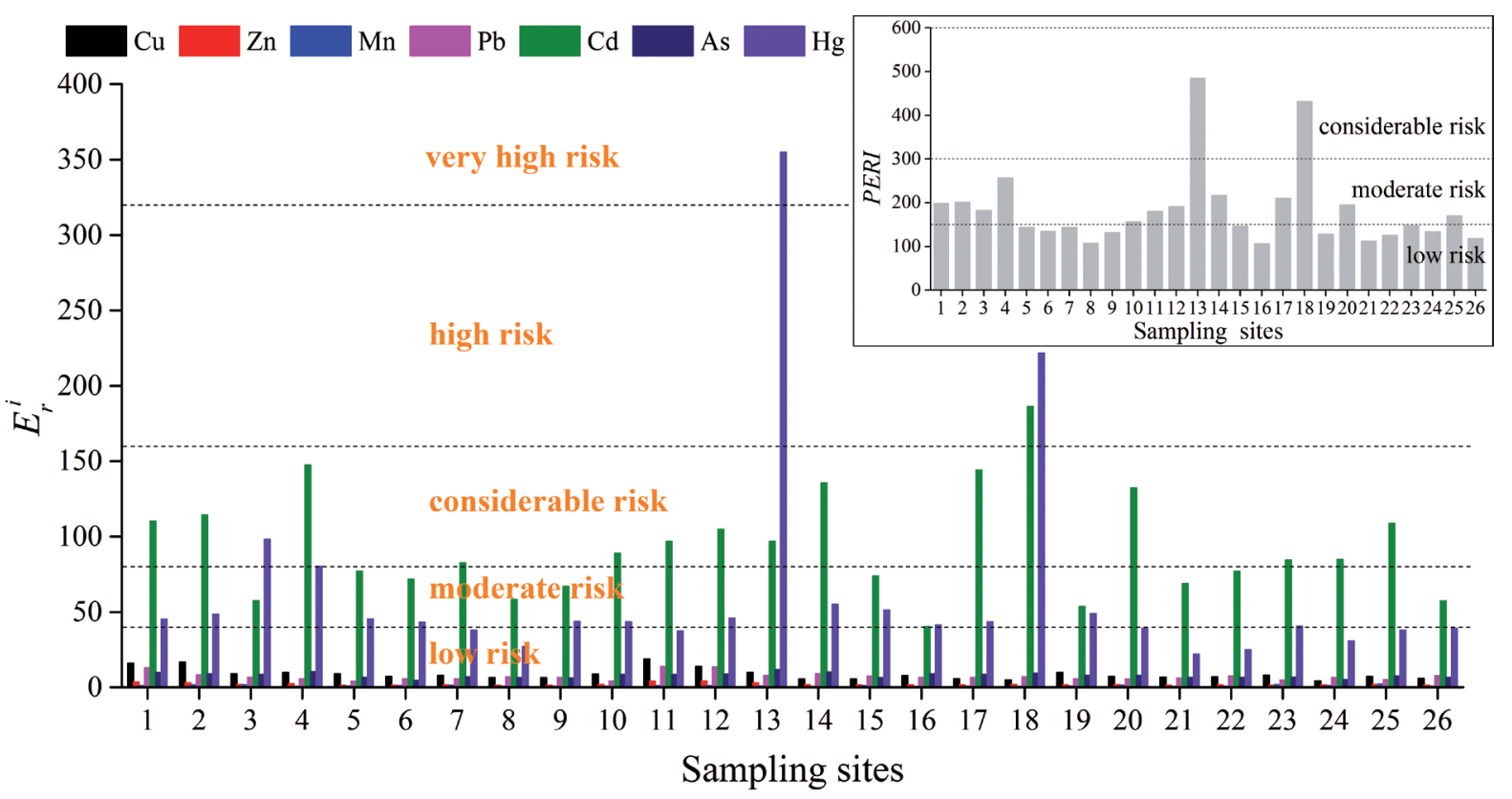

Fig. 5. The potential ecological risk index (PERI) of heavy metals in surface sediments of 26 sampling sites from the Wujiang River Basin. 
suggesting that these sampling sites had low ecological risk from combined metal pollution. However, the PERI was classified as considerable risk in sampling sites of 13 and 18 and moderate risk in sites of $1,2,3,4,10$, $11,12,14,20$, and 25. Therefore, it should pay more attention to the ecological risk of heavy metals from the Wujiang River Basin which will influence the Yangtze River ecosystem eventually.

\section{Conclusions}

The physic-chemical properties of overlying water and chemical speciation of $\mathrm{Cu}, \mathrm{Zn}, \mathrm{Mn}, \mathrm{Pb}, \mathrm{Cd}, \mathrm{As}$, and $\mathrm{Hg}$ in surface sediments from the Wujiang River Basin were studied. The results showed that the mean total concentrations of all heavy metals except As were higher than their background values. The higher $\mathrm{CV}$ values for selected heavy metals indicated that they were unevenly distributed and probably influenced by anthropogenic sources. The concentrations of most heavy metals in the presently studied area were relatively higher than that from the Pengxi River and the Jinsha River. It indicated that the Wujiang River could be a main pollution source of heavy metals within the Three Gorges Reservoir. No identical correlation between physic-chemical properties and heavy metal concentrations was showed, which suggested that these metals might be controlled by multiple factors. $\mathrm{Cu}, \mathrm{Zn}, \mathrm{Pb}, \mathrm{As}$, and $\mathrm{Hg}$ appear mostly in a residual fraction. The mean percentages of mobile fraction of heavy metals occurred in the following order: $\mathrm{Mn}>\mathrm{Cd}>\mathrm{Pb}>\mathrm{Zn}>\mathrm{Cu}>\mathrm{Hg}>\mathrm{As}$. The $\mathrm{Mn}$ and $\mathrm{Cd}$ were more mobile and bioavailable than other studied heavy metals. $\mathrm{Mn}$ and $\mathrm{Cd}$ were dominated by the reducible fraction and exchangeable fraction, respectively. The most important source of $\mathrm{Cd}$ in the Wujiang River Basin could be as a result of runoff containing phosphate fertilizer from the agricultural farms. The potential ecological risk of heavy metals in present study area were also assessed.

According to the RAC classification, $\mathrm{Cu}, \mathrm{Zn}, \mathrm{Pb}, \mathrm{As}$, and $\mathrm{Hg}$ posed a low risk in this studied area. $\mathrm{Mn}$ and $\mathrm{Cd}$ posed a high risk in most sampling sites. However, it cannot be ignored that the moderate risk of $\mathrm{Hg}$ in several sampling sites. The $I_{\text {geo }}$ classification showed that $\mathrm{Cd}$ has the highest environmental risk and the pollution levels of heavy metals in the surface sediments were generally in the sequence of $\mathrm{Cd}>\mathrm{Zn}>\mathrm{Cu}>\mathrm{Pb}>\mathrm{Hg}>\mathrm{Mn}>\mathrm{As}$. The PERI was classified as considerable risk in two sampling sites and moderate risk in ten sampling sites. So, it should pay much attention to the ecological risk of heavy metals from the Wujiang River Basin which will influence the Yangtze River ecosystem eventually.

\section{Acknowledgements}

This research was funded by the National Key Research and Development Program of China
(2016YFC0400702), Project funded by China Postdoctoral Science Foundation (2017M620431), Project of Guizhou Province Science and Technology (QKHPTRC [2017]5727-10), Key Laboratory of Soil Resources and Environment in Qianbei of Guizhou Province (Qian Jiao He KY Zi[2017]010, KLSREQ2018005), Fishery Resources and Environmental Science Experimental Station of the Upper-Middle Reaches of Yangtze River Ministry of Agriculture (No. 2016ESOF-04). We thank Zhi Li from Oklahoma State University for his language modification during the preparation of this manuscript.

\section{Conflict of Interest}

The authors declare no conflict of interest.

\section{References}

1. ÁlVAREZ-V ZQUEZ M.Á., PREGO R., CAETANO M., DE U A-ÁlVAREZ E., DOVAL M., CALVO S., VALE C. Contributions of trace elements to the sea by small uncontaminated rivers: Effects of a water reservoir and a wastewater treatment plant. Chemosphere, 178, 173, 2017.

2. MIC C., RECATAL L., PERIS M., S NCHEZ J. Assessing heavy metal sources in agricultural soils of an European Mediterranean area by multivariate analysis. Chemosphere, 65, 863, 2006.

3. PAN K., WANG W.X. Trace metal contamination in estuarine and coastal environments in China. Sci. Total Environ., 421-422, 3, 2012.

4. LI R., TANG X., GUO W., LIN L., ZHAO L., HU Y., LIU M. Spatiotemporal distribution dynamics of heavy metals in water, sediment, and zoobenthos in mainstream sections of the middle and lower Changjiang River. Sci. Total Environ., 714, 136779, 2020.

5. ZHANG Z., JUYING L., MAMAT Z., QINGFU Y. Sources identification and pollution evaluation of heavy metals in the surface sediments of Bortala River, Northwest China. Ecotox. Environ. Safe., 126, 94, 2016.

6. KANG M., TIAN Y., PENG S., WANG M. Effect of dissolved oxygen and nutrient levels on heavy metal contents and fractions in river surface sediments. Sci. Total Environ., 648, 861, 2019.

7. SAKAN S.M., ĐORĐEVIĆ D.S., MANOJLOVIĆ D.D., PREDRAG P.S. Assessment of heavy metal pollutants accumulation in the Tisza river sediments. J. Environ. Manage., 90, 3382, 2009.

8. ZHANG C., SHAN B., TANG W., DONG L., ZHANG W., PEI Y. Heavy metal concentrations and speciation in riverine sediments and the risks posed in three urban belts in the Haihe Basin. Ecotox. Environ. Safe., 139, 263, 2017.

9. MOSSOP K.F., DAVIDSON C.M. Comparison of original and modified BCR sequential extraction procedures for the fractionation of copper, iron, lead, manganese and zinc in soils and sediments. Anal. Chim. Acta, 478, 111, 2003.

10. KE X., GUI S., HUANG H., ZHANG H., WANG C., GUO W. Ecological risk assessment and source identification for heavy metals in surface sediment from the Liaohe River protected area, China. Chemosphere, 175, 473, 2017. 
11. MORELLI G., GASPARON M. Metal contamination of estuarine intertidal sediments of Moreton Bay, Australia. Mar. Pollut. Bull., 89, 435, 2014.

12. DELGADO J., BARBA-BRIOSO C., NIETO J.M., BOSKI T. Speciation and ecological risk of toxic elements in estuarine sediments affected by multiple anthropogenic contributions (Guadiana saltmarshes, SW Iberian Peninsula): I. Surficial sediments. Sci. Total Environ., 409, 3666, 2011.

13. GUSTIN M.S., LINDBERG S., MARSIK F., CASIMIR A., EBINGHAUS R., EDWARDS G., HUBBLEFITZGERALD C., KEMP R., KOCK H., LEONARD T., et al. Nevada STORMS project: Measurement of mercury emissions from naturally enriched surfaces. J. Geophys. Res. Atmos., 104, 21831, 1999.

14. ZHAO L., GUO Y., MENG B., YAO H., FENG X. Effects of damming on the distribution and methylation of mercury in Wujiang River, Southwest China. Chemosphere, 185, 780, 2017.

15. FENG X., JIANG H., QIU G., YAN H., LI G., LI Z. Mercury mass balance study in Wujiangdu and Dongfeng Reservoirs, Guizhou, China. Environ. Pollut., 157, 2594, 2009.

16. GUO Y.N., FENG X.B., LI Z.G., HE T.R., YAN H.Y., MENG B., ZHANG J.F., QIU G.L. Distribution and wet deposition fluxes of total and methyl mercury in Wujiang River Basin, Guizhou, China. Atmos. Environ., 42, 7096, 2008.

17. MA Y.Q., QIN Y.W., ZHENG B.H., ZHAO Y.M., ZHANG L., YANG C.C., SHI Y., WEN Q. Three Gorges Reservoir: metal pollution in surface water and suspended particulate matter on different reservoir operation periods. Environ. Earth Sci., 75, 1413, 2016.

18. JIANG H., FENG X., DAI Q. Damming effect on the distribution of mercury in Wujiang River. Chinese Journal of Geochemistry, 24, 179, 2005.

19. NEMATI K., BAKAR N.K.A., ABAS M.R., SOBHANZADEH E. Speciation of heavy metals by modified BCR sequential extraction procedure in different depths of sediments from Sungai Buloh, Selangor, Malaysia. J. Hazard. Mater., 192, 402, 2011.

20. M LLER G. Index of geoaccumulation in sediments of the Rhine River. GeoJournal, 2, 109, 1969.

21. HE S. Geochemical background of supergene sediments in Guizhou. Guizhou Geology, 15, 149, 1998 [In Chinese].

22. FARKAS A., ERRATICO C., VIGAN L. Assessment of the environmental significance of heavy metal pollution in surficial sediments of the River Po. Chemosphere, 68, 761, 2007.

23. HAKANSON L. An ecological risk index for aquatic pollution control. a sedimentological approach. Water Res., 14, 975, 1980.

24. DENG M., YANG X., DAI X., ZHANG Q., SADEGHPOUR A. Heavy metal pollution risk assessments and their transportation in sediment and overlay water for the typical Chinese reservoirs. Ecol. Indic., 112, 106166, 2020.

25. ZHU J., LI S.L., WANG Y.C., YAN H.Y., LIAO L.M., ZHONG J. Spatial characters of nutrients in Wujiangdu Reservoir in karst river, SW China. Acta Geochim. 36, 605, 2017.

26. YAN HY, FENG XB, SHANG LH, QIU GL, DAI QJ, WANG SF, HOU YM. The variations of mercury in sediment profiles from a historically mercurycontaminated reservoir, Guizhou province, China. Sci. Total Environ., 407, 497, 2008.
27. LIU Y., MA Z.W., LV J.S., BI J. Identifying sources and hazardous risks of heavy metals in topsoils of rapidly urbanizing East China. J. Geogr. Sci., 26, 735, 2016.

28. LIN J., ZHANG S., LIU D., YU Z., ZHANG L., CUI J., XIE K., LI T., FU C. Mobility and potential risk of sediment-associated heavy metal fractions under continuous drought-rewetting cycles. Sci. Total Environ., 625, 79, 2018.

29. YUAN Q., WANG P., WANG C., CHEN J., FENG T. Metals and metalloids distribution, source identification, and ecological risks in riverbed sediments of the Jinsha River, China. J. Geochem. Explor., 205, 106334 , 2019.

30. WANG L., WANG Y., ZHANG W., XU C., AN Z. Multivariate statistical techniques for evaluating and identifying the environmental significance of heavy metal contamination in sediments of the Yangtze River, China. Environ. Earth Sci., 71, 1183, 2014.

31. SHUI L., PAN X., CHEN X., CHANG F., WAN D., LIU D., HU M., LI S., WANG Y. Pollution characteristics and ecological risk assessment of heavy metals in sediments of the Three Gorges Reservoir. Water, 12, 1798, 2020.

32. HE Z., LI F., DOMINECH S., WEN X., YANG S. Heavy metals of surface sediments in the Changjiang (Yangtze River) Estuary: Distribution, speciation and environmental risks. J. Geochem. Explor., 198, 18, 2019.

33. HU J., ZHOU S., WU P., QU K. Assessment of the distribution, bioavailability and ecological risks of heavy metals in the lake water and surface sediments of the Caohai plateau wetland, China. Plos One, 12, e0189295, 2017.

34. K KRER S., SEKER S., MURATHAN Z.T., KUTLU B. Ecological risk assessment of heavy metals in surface sediments of northern littoral zone of Lake Cildir, Ardahan, Turkey. Environ. Monit. Assess., 186, 3847, 2014.

35. ZHENG B., LU S., WU J., GUO X., WU F., LI X., HE Q., FU Z., XU L. Heavy metal distribution in Tiaoxi River's sediment. Environ. Sci. Pollut. R., 25, 2603, 2018.

36. JI H., LI H., ZHANG Y., DING H., GAO Y., XING Y. Distribution and risk assessment of heavy metals in overlying water, porewater, and sediments of Yongding River in a coal mine brownfield. J. soil sediment, 18, 624, 2018.

37. THOMAS R.P., URE A.M., DAVIDSON C.M., LITTLEJOHN D., RAURET G., RUBIO R., L PEZ-S NCHEZ J.F. Three-stage sequential extraction procedure for the determination of metals in river sediments. Anal. Chim. Acta, 286, 423, 1994.

38. CAI S., ZHOU S., WU P., ZHAO J. Speciation and bioavailability of metals in sediments from a stream impacted by abandoned mines in Maoshi Town, Southwest of China. B. Environ. Contam. Tox., 103, 302, 2019.

39. XU D., WANG Y., ZHANG R., GUO J., YU K. Distribution, speciation, environmental risk, and source identification of heavy metals in surface sediments from the karst aquatic environment of the Lijiang River, Southwest China. Environ. Sci. Pollut. R., 23, 9122, 2016.

40. MA X., ZUO H., TIAN M., ZHANG L., MENG J., ZHOU X., MIN N., CHANG X., LIU Y. Assessment of heavy metals contamination in sediments from three adjacent regions of the Yellow River using metal chemical fractions and multivariate analysis techniques. Chemosphere, 144, 264, 2016. 
41. SUNDARAY S.K., NAYAK B.B., LIN S., BHATTA D. Geochemical speciation and risk assessment of heavy metals in the river estuarine sediments - A case study: Mahanadi basin, India. J. Hazard. Mater., 186, 1837, 2011.

42. ISLAM M.S., AHMED M.K., RAKNUZZAMAN M., HABIBULLAH -AL- MAMUN M., ISLAM M.K.
Heavy metal pollution in surface water and sediment: A preliminary assessment of an urban river in a developing country. Ecol. Indic., 48, 282, 2015.

43. VAN HOP N., THI QUYNH DIEU H., HAI PHONG N. Metal speciation in sediment and bioaccumulation in Meretrix lyrata in the Tien Estuary in Vietnam. Environ. Monit. Assess., 189, 299, 2017. 
